\title{
Implementasi Etika Kristen Dalam Keluarga Badan Pengurus Jemaat Gereja Kemah Injil Indonesia Propinsi Jawa Tengah
}

\author{
Jamin Tanhidy ${ }^{1}$, Muner Daliman ${ }^{2}$, Hana Suparti ${ }^{3}$, Krido Siswanto $^{4}$ \\ ${ }^{1,4}$ Sekolah Tinggi Teologi Simpson Ungaran, ${ }^{2,}{ }^{3}$ Sekolah Tinggi Teologi Kadesi Yogyakarta \\ Email: 1jamin-tanhidy@sttsimpson.ac.id
}

\begin{abstract}
Family institution as the smallest unit of the human institutional system, like an organization, need rules and a code of ethics in order to run well. If ethics is not consistently applied in a family, it will have a negative impact on the harmony and quality of family, which in turn has a bad impact on the church, school, community and nation. Therefore, the aim of this Applied Research is to find out the level and what the most dominant indicators that tend to determine the implementation of Christian Ethics in the Family of the Church Leaders of Alliance Church in Central Java Province. This research using Quantitative Method based on aexegetical study text from Ephesians 5: 22-6: 4 in order to find out the indicators that determine the research. About 120 people are taking as a sample, using the Non Random Sampling Technique, data computed by SPSS Programme version 20. The result showed that, first, the level of implementation of Christian ethics in the family based on Ephesians 5: 22-6: 4 among The Church Leaders of Alliance Church in Central Java Province is in the category "Medium", This condition caused by pragmatic pastoral leadership patterns that took priority on church marketing and lackof synergy between church, family and school in realizing implementation of Christian Ethics in the Family. Second, Physical Aspect more determine the implementation of Christian ethics in the family among The Church Leaders. The results of this research indicate that the Physical and Theological Aspects are closely related (link) with each other as the main catalyst influencing the implementation of Christian ethics in the family which can ultimately build the body of Christ and create healthy church growth. Therefore, the church needs to value both aspects proportionally.
\end{abstract}

Keywords: Christian Ethics, Family, Implementation, The Chucrh Leaders

\begin{abstract}
ABSTRAK: Lembaga keluarga sebagai satuan terkecil dari sistem kelembagaan manusia, layaknya sebuah organisasi memerlukan peraturan dan kode etik agar berjalan baik. Jika etika tidak diterapkan secara konsisten dalam sebuah keluarga, maka akan membawa dampak negatif bagi keharmonisan dan kualitas keluarga yang berdampak buruk kepada gereja, sekolah, masyarakat dan bangsa. Oleh sebab itu, Penelitian Terapan (Applied Research) ini bertujuan untuk mengetahui berapa besar tingkat dan dimensi mana yang dominan menentukan, implementasi etika Kristen dalam keluarga Badan Pengurus Jemaat Gereja Kemah Injil Indonesia (BPJ GKII) di Propinsi Jawa Tengah. Penelitian ini menggunakan metode penelitian kuantitatif dan eksegesis terhadap nats Efesus 5:22-6:4 sebagai landasan teori dan menemukan indikator penelitian. Sampel penelitian sebanyak 120 orang, teknik pengambilan sampel dengan Non-Random Sampling, penghitungan data memakai SPSS 20. Hasil penelitian menunjukkan: pertama, tingkat implementasi etika Kristen berdasarkan Surat Efesus 5:22-6:4 dalam keluarga BPJ GKII Propinsi Jawa Tengah berada dalam ketegori sedang. Hal ini disebabkan oleh pola pengembalaan pragmatis yang lebih berorientasi pada pemasaran organisasi gereja serta lemahnya sinergi antara gereja, keluarga dan sekolah dalam mewujudkan implementasi etika Kristen dalam keluarga. Kedua, aspek fisik dalam dimensi relasi suami-istri merupakan indikator yang paling dominan menentukan implementasi etika Kristen dalam keluarga BPJ GKII Propinsi Jawa Tengah. Hasil riset ini menunjukkan bahwa aspek fisik dan teologis saling terkait erat (link) satu sama lain sebagai katalisator utama yang mempengaruhi implementasi etika Kristen dalam keluarga yang akhirnya dapat membangun tubuh Kristus dan menciptakan pertumbuhan gereja yang sehat. Oleh karena itu, gereja perlu menghargai kedua aspek ini secara proporsional.
\end{abstract}

Kata Kunci: Etika Kristen, Keluarga, Implementasi, Badan Pengurus Jemaat. 


\section{PENDAHULUAN}

Etika Kristen merupakan sikap dan perilaku kehidupan orang Kristen yang berpedoman kepada Alkitab sebagai firman Allah. Secara etimologi kata etika berasal dari kata Yunani Kuno ethos dimana kata ini dalam bentuk tunggal berarti padang rumput, kandang, tempat tinggal yang biasa, adat, akhlak, kebiasaan, perasaan, sikap watak, cara berpikir (Bertens, 1994, p. 4). Verkuyl (1985, p. 15) menjelaskan arti kata ethos dalam arti kesusilaan, perasaan batin atau kecenderungan hati dimana seseorang melakukan sesuatu perbuatan. Dalam bentuk jamak taetha artinya adalah adat kebiasaan. Kata yang terakhir ini oleh filsuf Yunani Aristoteles (384-322 SM) dipakai menjadi filsafat moral. Saat ini, kata etika lebih sering dipahami dalam arti jamak. Darmaputera (2009, p. 102) menjelaskan bahwa etika Kristen semestinya bertitiktolak dari pemahaman bahwa manusia sebagai gambar Allah (Imago Dei) dimana setiap keputusan dan penilaian etis secara kristiani harus bersifat menghargai dan menghormati hakekat manusia yang istimewa tersebut. Menurut Sproul (2005, p. 28) orang Kristen menegaskan imannya bahwa Tuhan, Allah menjadi pusat segala sesuatu dan sifat-Nya merupakan standar mutlak pedoman benar dan salah. Etika Kristen berpusat pada Allah dan standar firman-Nya (Teosentris) dan menurut Kraft (1996, p. 119) mencakup keutuhan atau totalitas fungsi-fungsi (Functions) dan kebutuhan-kebutuhan (Needs) manusia yaitu aspek spiritual, sosial, moral dan fisik.

Lembaga keluarga merupakan lembaga tertua dibentuk oleh Allah dan diberi-Nya mandat untuk beranakcuculah dan bertambah banyak (Kej. 1:28). Suatu lembaga tentu memerlukan aturan main, etika dan peraturan tidak terkecuali lembaga keluarga. Surat Efesus 5:22-6:4 menjelaskan prinsip-prinsip kehidupan keluarga Kristen dan aspek di dalamnya berupa aspek rohani, sosial dan fisik (Wiersbe, 1983, p. 135). Senada dengan itu, McDonald (1999, p. 72) menjelaskan aspek-aspek lengkap sebagai standar lebih tinggi dalam sebuah keluarga berupa aspek fisik ( $p h y$ sical), aspek emosi (emotional), aspek sosial (social) dan aspek rohani (spiritual).
Dalam Surat Efesus 5:22-6:4 dapat ditarik keluar dua dimensi utama yang menjadi fokus penelitian ini yaitu: pertama, dimensi relasi suami-istri (D1); kedua, dimensi relasi orang tua-anak (D2). Masing-masing dimensi tersebut di dalamnya terdapat aspek-aspek yang tersirat dalam Surat Efesus tersebut di atas yaitu aspek rohani, sosial, moral dan fisik.

Relasi antar anggota keluarga Kristen didasarkan kepada etika (Efesus 5:22-6:4) karena pernikahan Kristen memiliki tujuan yang jauh melebihi tujuan pernikahan pada umumnya yaitu menyatakan kemuliaan Allah lewat pertumbuhan (kedewasaan hubungan) sepasang suami-istri dalam aspek rohani, sosial, moral dan fisik di dalamnya terpancar kasih Allah sebagai lambang relasi antara Yesus Kristus dan gereja-Nya. Relasi suami-istri tidak hanya untuk pemuasan atau pemenuhan diri, melainkan pemenuhan panggilan ilahi (Pardede, 2019, p. 70-71) sebagai tanggungjawab iman dalam keluarga (Ef. 5:23; Kol. 3:18-21; Ams. 31:12-13; Ul. 6:5-7) yang mengingatkan tanggung jawab seorang istri, suami dan anakanak yang ideal (Hutahaean, 2019, p. 51). Dalam artikel penelitian ini, pengunaan istilah keluarga dan rumah tangga disamakan pengertiannya dan dibahas secara integratif, meskipun ada beberapa pakar atau ahli membedakan pemakaian kedua istilah tersebut. Hal ini didasari dengan pertimbangan bahwa fokus penelitian ini membahas keluarga Kristen secara holistik mencakup aspek rohani, sosial, moral dan fisik sebagai indikator penelitian.

Dalam Relasi suami-istri mengenai aspek rohani, prinsip utama dijelaskan bahwa para istri semestinya bersikap tunduk kepada para suami atau menaklukkan diri kepada otoritas suami sebagai kepala keluarga (Larosa, Yuwanda, 2009, p. 46-48) sama seperti Kristus adalah Kepala jemaat (Ef. 5:22, 25). Disini kedudukan suami sebagai kepala dalam keluarga. Kata kepala ( $\kappa \varepsilon \varphi \alpha \lambda \eta)$ dipakai sebanyak $75 \mathrm{x}$ dalam Alkitab Perjanjian Baru artinya merujuk kepada ke-

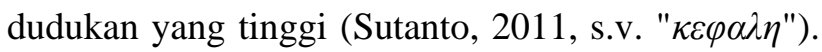
Yang juga bertindak menjadi imam dalam keluarga. Tugas suami sebagai kepala adalah menjadi penyelamat $($ soter $=\sigma \omega \tau \eta \rho)$ yang mencukupkan kebutuhan 
keluarga baik rohani, sosial, moral dan fisik meski sulit dan tidak mungkin sempurna namun harus diperjuangkan dengan segala upaya (Osborne, 1992, p. 6667). Prinsip penting lainnya, suami diperintahkan untuk mengasihi istri, sama seperti Kristus telah mengasihi jemaat (Ef. 5:25). Kata 'kasihilah' dalam ayat ini memakai bentuk kalimat Present Imperative Active orang kedua jamak, bersifat perintah aktif kekinian. Artinya para suami diperintahkan Tuhan untuk senantiasa mengasihi istrinya, sama seperti Kristus telah mengasihi jemaat-Nya. Ini bukan pilihan tapi perintah. Dengan demikian, aspek rohani memainkan peranan terpenting dan menjadi indikator utama bagi terwujudnya implementasi etika Kristen dalam keluarga.

Aspek kedua adalah aspek sosial. Aspek sosial berperan penting juga dalam mewujudkan implementasi etika Kristen dalam keluarga (Ef. 5: 26). Kata 'menyucikannya' ( $\kappa \alpha \theta \alpha \rho i \zeta \omega=$ katharizo) dari ayat 26 ini menyiratkan aspek rohani dan sosial, dimana Kristus menyucikan jemaat-Nya agar menjadi cemerlang tanpa cacat atau kerut atau yang serupa itu. Disini ada nilai penghargaan, komunikasi dan kebersamaan. Oleh karena itu, prinsip penting dalam aspek sosial ialah bahwa suami-istri harus saling menghargai atau menghormati (Ef. 5:33). Sikap saling menghargai ini merupakan wujud dari cinta yang berakar kuat di tanah subur sebagai karunia Allah dan menjadi fondasi abadi bagi pernikahan (Christenson, n.d., p. 26). Prinsip lainnya, suami-istri perlu memiliki komunikasi yang terbuka dihadapan Allah yang dilandasi komitmen mentaati perintah Tuhan, guna mempertahankan keintiman dan cinta dengan menghindari masalah kesibukan, pengiraan dan pra-anggapan, cara bertukar pikiran yang tidak membangun tembok (Scheunemann, 1988). Selain itu, suami-istri sepatutnya memiliki Quality Time, yaitu waktu bersama antara suami-istri untuk saling memahami, berbagi pengalaman kehidupan, perhatian dan kasih. Aspek sosial mendorong terwujudnya implementtasi etika Kristen dalam keluarga.

Aspek ketiga adalah aspek moral. Dalam Efesus 5:27 terdapat kata "menempatkan" ( $\pi \alpha \rho i \sigma \tau \eta \mu l$ = paristemi) yang memiliki implikasi moral berupa "kepercayaan, pengawasan dan penerimaan". Untuk itu, suami-istri patut saling percaya satu sama lain, mengawasi kelakuan pasangan dan menerima kelebihan atau kekurangan pasangan. Sikap yang terakhir ini, yaitu berupa kasih dan penerimaan tanpa syarat merupakan kebutuhan paling utama (prioritas) suami dan istri dalam kehidupan pernikahan menurut survei terhadap 700 pasangan (Ngir, 2014).

Aspek keempat adalah aspek fisik (physical). Nats Efesus 5:28-31 menjelaskan tugas suami yang harus mengasihi istrinya sama seperti tubuhnya sendiri, mengasuh dan merawatnya karena telah dipersatukan oleh Allah menjadi satu daging. Kata "meng-

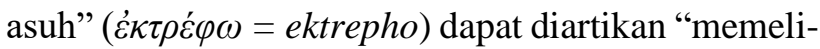
hara" dan kata "merawat" $(\theta \dot{\alpha} \lambda \pi \omega=$ thalpo $)$ maksudnya "mendewasakan". Aspek fisik ini mencakup dukungan finansial (Parrott III, Parrott, 1999), kesehatan pasangan dan sexual fulfillment (Ngir, 2014; Wiersbe, 1983).

Dimensi kedua yang diteliti ialah relasi orang tua-anak yang merupakan bagian integral dibicarakan dalam Surat Efesus 6:1-4 tentang keluarga Kristen. Kekristenan tidak pernah menyepelekan anak-anak, melainkan mendidik dan menyambutnya sebagai aset ilahi (Beeke, 2019; Meade, 2019; Tong, 2019). Dalam budaya Romawi waktu itu terjadi krisis moral berdampak pada hancurnya lembaga pernikahan dan banyak anak-anak dibuang, dijual sebagai budak atau dibawa ke rumah-rumah pelacuran (Barclay, 2003, p. 269). Paulus ingin mengangkat derajat keluarga dan hak anak-anak yang diabaikan waktu itu. Dengan menekankan pentingnya relasi orang tua-anak dalam dalam beberapa aspek yaitu:

Pertama, aspek rohani. Dalam aspek ini, anak-anak harus mentaati ajaran orang tua (Ef. 6:1).

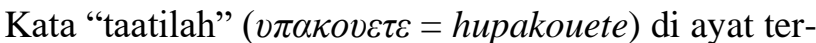
sebut memakai kata kerja (verb) bentuk present plural active imperative atau kata kerja aktif jamak kekinian bersifat perintah, artinya "taati, membuka pintu”. Anak-anak diperintahkan oleh firman Tuhan agar senantiasa aktif untuk membuka diri atau pintu hati bagi semua bimbingan, nasihat, didikan, teguran dan ajaran orang tuanya. Kata "haruslah demikian" 
$(\delta \imath$ lkııov $=$ dikaion $)$ artinya "benar, adil, patut dan punya hubungan yang benar" atau baik dengan orang tuanya. Prinsip lainnya, orang tua dituntut menjadi teladan bagi anak-anak. Dalam kebudayaan Romawi, ada hukum yang disebut dengan Patria Potestas, yaitu kuasa mutlak yang dimiliki seorang ayah Romawi dalam keluarganya. Hukum ini memberi peluang bagi seorang ayah sesuka hati bertindak terhadap anakanaknya. Ada yang menjual anaknya menjadi budak, bekerja kasar di ladang, menghukum semena-mena, bahkan sampai membawa maut. Kuasa ini berlaku sepanjang si ayah itu hidup, sehingga anak-anak Romawi terkesan tidak pernah menjadi orang dewasa sepenuhnya, meskipun sudah menjadi orang ternama atau berjasa (Barclay, 2003). Profil ayah yang otoriter di atas, sulit dijadikan teladan. Oleh sebab itu, Paulus mengajak para ayah untuk mendidik anak-anak dengan ajaran dan nasehat dari Tuhan (Ef. 6: 4) karena anak-anak sangat membutuhkan figur ayah yang bisa diteladani atau christian nurture (Hadinoto, 2012, p. 211; Morley, 2009; Thomas, 2000).

Kedua, aspek sosial. Aspek ini erat kaitannya dengan pemenuhan kebutuhan anak untuk "diterima, mencintai dan dicintai." Sering kali orang tua baru bisa menerima anaknya yakni ketika mereka berprestasi. Anak yang tertolak mudah rapuh terhadap tekanan kelompoknya, lalu berkelahi untuk mendapatkan penerimaan, bahkan tidak sedikit yang mengira Tuhan telah membencinya (Drescher, 2009). Sikap penolakkan terhadap anak menggangu kehidupan sosialnya. Dalam Efesus 6:4 ada kata "nasihat"

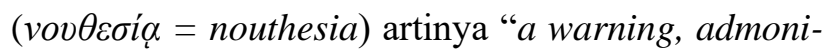
tion, counsel." Kata ini mengandung nilai-nilai sosial berupa nilai penerimaan, kesabaran, penghargaan, peringatan dan arahan. Disini, Anak-anak perlu ditumbuhkan kepercayaan dirinya (self-esteem), bersosialisasi dalam kelompoknya (social interaction) dan dibentuk kesadaran dirinya (conscientization). Anak jangan dilindungi berlebihan (over-protective), melainkan diajak berinteraksi dalam keluarga (family time) dan diawasi pergaulannya serta dilibatkan dalam kegiatan sosial (intentional socialization) di ge- reja dan masyarakat (Banks, Stevens, 2012; Biyanto \& Limengka, 2019; Calvin, 2015; Pratama, 2012).

Ketiga, aspek moral. Dalam Efesus 6:2-3, kata "Hormatilah" $(\tau i \mu \alpha \omega=$ tima'o) artinya menetapkan harga, menghormati dengan dukungan keuangan serta memberi penghargaan (Sutanto, 2011). Kata ini merupakan bentuk kata kerja aktif kekinian bersifat perintah (present active imperative), artinya setiap anak diperintahkan Allah menghormati, menghargai dan memelihara orang tuanya, termasuk kebutuhan secara finansial. Sebaliknya, orang tua mendidik moral anak sebagai sarana pelatihan dasar bertahan hidup, penanaman dan pewarisan nilai-nilai kehidupan dan pendidikan (Hadinoto, 2012), (Antone, 2010).

Dalam Efesus 6:4 terdapat kata " $\pi \alpha \rho o \rho \gamma l \zeta \varepsilon \tau \varepsilon "$ (parorgizete) dari kata dasar " $\pi \alpha \rho o \rho \gamma \iota \zeta \omega "$ (parorgizo) artinya "membangkitkan amarah." Ayat ini melarang kaum bapak bersikap kasar, otoriter dan memusuhi anak, sehingga anak menjadi marah atau sakit hati dan menjadi patah semangat menerima nasehat bapaknya. Karakter anak bisa menjadi buruk karena lemahnya pengajaran nilai moral dalam keluarga (Nuhamara, 2018). Dalam Ef. 6:4b ada kata "ajaran" $(\pi \alpha l \delta \varepsilon l \alpha=$ Paideia $)$ artinya "mendidik dengan mengajar, menuntun, atau menghukum." Para ayah memberi disiplin kepada anak ketika berbuat salah. Proporsi rasa bersalah yang tepat membantu mencegah perilaku buruk anak (Melgosa, Borges, 2017). Kecerdasan moral anak adalah hasil dari meneladani sikap dan tindakan orang tua di rumah, di sekolah dan cara bersikap dengan sesama (Coles, 2000, p. 576).

Keempat, aspek fisik. Dalam Ef. 6:4 ada kata "didiklah" ( $\varepsilon \kappa \tau \varepsilon \varphi \varphi \varepsilon \tau \varepsilon=$ ektrephete), dari kata dasar

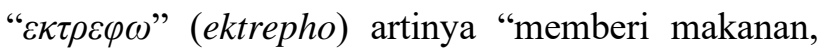
mengasuh" (Sutanto, 2011). Untuk itu, orang tua perlu mencukupi kebutuhan jasmani (namun jangan berlebihan) dan menjaga kesehatan anak, serta tidak mengabaikan pendidikan sosial, moral dan rohani anak. Aspek fisik juga menyangkut keterbukaan orang tua ketika anak-anak bertanya soal seks (Otis, 2003), serta diajar untuk merawat orang tuanya di hari tuanya. Pada akhirnya, orang tua dan anak perlu 
bekerjasama merancang masa depan atau visi keluarga bersama (Groome, 2011).

Secara umum, penelitian ini didasari dengan pertimbangan untuk meneliti relasi dalam keluarga secara utuh dan bersamaan yaitu relasi suami-istri dan relasi orang tua-anak serta kebutuhan keluarga secara holistik berupa aspek rohani, sosial, moral dan fisik. Beberapa penelitian akhir-akhir ini berkaitan dengan keluarga kebanyakkan menyangkut masalah ekonomi (Dewi, 2012; Nugraheni S., 2012; Rochaida, 2016; Salaa, 2015) dan pola asuh orang tua (Longkutoy, Sinolungan, Opod, 2015), tidak mencakup keseluruhan aspek. Secara khusus, penelitian ini didasari pertimbangan bahwa penelitian yang berkaitan dengan etika Kristen dalam keluarga banyak berkaitan dengan Pendidikan Agama Kristen terutama menyangkut relasi orang tua dan anak (Tafonao, 2018), pendidikan karakter dalam konteks gereja, keluarga dan sekolah (Debora, Han, 2020; Nuhamara, 2018), dalam tatanan konseptual. Sementara itu, penelitian ini dilakukan untuk mengetahui bagaimana hasil penerapan etika Kristen itu dalam sebuah keluarga secara faktual. Di samping itu, faktor pandemi covid-19 yang menyebabkan krisis multidimensi, terutama sosial, ekonomi, politik (Daud, 2020, p. 39), pendidikan (Mansyur, 2020) termasuk komunikasi dalam keluarga (Kaddi, Lestari, \& Adrian, 2020) juga menjadi faktor yang mempengaruhi penelitian ini. Obyek penelitian yaitu keluarga Badan Pengurus Jemaat Gereja Kemah Injil Indonesia (BPJ GKII) di Propinsi Jawa Tengah. Wabah covid-19 secara otomatis ikut mendatangkan krisis dalam kehidupan keluarga BPJ GKII, baik itu menyangkut aspek rohani, sosial, moral dan fisik. Disini implementasi etika Kristen dalam keluarga menjadi penting untuk dicermati atau diteliti. Tentunya yang dimaksud adalah etika yang berpedoman kepada alkitab, terutama Surat Efesus 5:22-6:4.

Rumusan Masalah yang diajukan yaitu Pertama, "Berapa besar tingkat implementasi etika Kristen dalam keluarga berdasarkan Surat Efesus 5:22-6:4 di kalangan BPJ GKII di propinsi Jawa Tengah. Kedua, "Indikator apa yang dominan menentukan terimplementasinya etika Kristen dalam keluarga BPJ
GKII di propinsi Jawa Tengah berdasarkan Surat Efesus 5:22-6:4."

Tujuan Penelitian ini ialah. Pertama, mengetahui tingkat implementasi etika Kristen dalam keluarga BPJ GKII di Propinsi Jawa Tengah berdasarkan Surat Efesus 5:22-6:4. Kedua, menjelaskan indikator dominan yang menentukan penerapan etika Kristen obyek penelitian di atas.

\section{METODE}

Riset ini memakai metode penelitian kuantitatif. Landasan teori dibangun berdasarkan studi eksegesis terhadap Surat Efesus 5:22-6:4 yang memperoleh 2 dimensi utama yaitu dimensi 1 (D1) berupa relasi suami-istri (Efesus 5:22-33) dan dimensi 2 (D2) berupa relasi orang tua-anak (Efesus 6:1-4). Setiap Dimensi terdiri dari indiktor berupa Aspek Teologis, Aspek Sosial, Aspek Moral dan Aspek Fisik. Total ada 8 indikator yang diteliti (I1 -I8).

Populasi penelitian mencapai 300 orang, maka sampel penelitian adalah $40 \%$ dari jumlah populasi (Arikunto, 2008, p. 116) yaitu sebanyak 120 orang anggota BPJ GKII di Jawa Tengah yang tersebar di 30 gereja lokal dan 3 buah Pos Penginjilan (data tahun 2019). Teknik pengambilan sampel dengan non-random sampling (tidak semua populasi terwakili) karena keterbatasan dana, waktu dan keluasan daerah penelitian, serta fokus penelitian pada anggota BPJ yang sudah berkeluarga. Instrumen penelitian final berupa angket (45 butir), divalidasi oleh 4 validator dan diuji coba kepada 30 orang sampel memakai stastistical product service solution (SPSS versi 20). Teknik analisis data dengan Uji Persyaratan Analisis, setelah itu dilakukan Uji Hipotesis.

\section{HASIL}

\section{Uji Persyaratan Analisis}

\section{Uji Normalitas}

Uji normalitas dilakukan dengan gambar PPlot terhadap setiap indikator yang ada dalam dimensi penelitian. 
Estimated Distribution Parameters

\begin{tabular}{|l|l|c|}
\hline \multicolumn{2}{|c|}{} & Relasi Suami Istri \\
\hline $\begin{array}{l}\text { Normal } \\
\text { Distribution }\end{array}$ & Location & 101.4778 \\
\cline { 2 - 3 } & Scale & 8.07998 \\
\hline
\end{tabular}

The cases are unweighted.

Tabel 1. Distribusi Parameter D1 - Dimensi Relasi Suami-Istri

Uji Normalitas setiap indikator Dimensi Relasi Suami-Istri yaitu:

Indikator 1 - Aspek Teologis Relasi Suami-Istri

Dari gambar P-P plot dari indikator 1 aspek teologis relasi suami-istri di atas menunjukan bahwa data berdistribusi secara normal karena titik-titik (Plot) mengikuti garis diagonal.

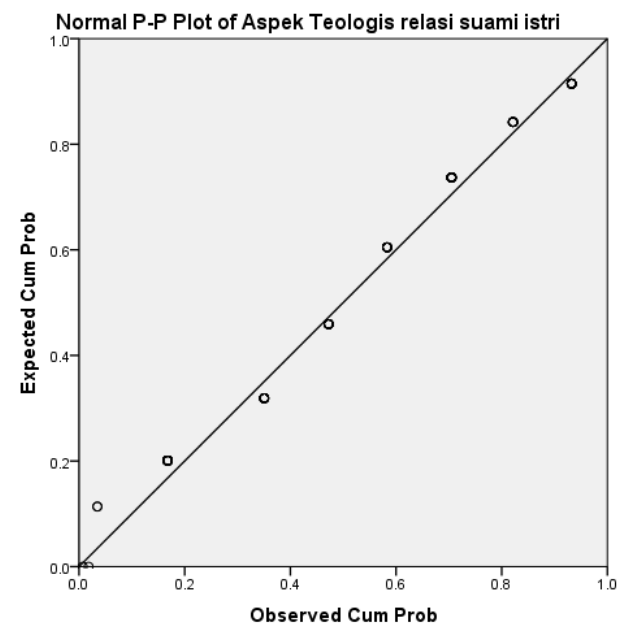

Gambar 1. P-P Plot Aspek Teologis

Indikator 2 - Aspek Sosial Relasi Suami-istri

Dari gambar P-P plot dari indikator 2 aspek sosial relasi suami-istri di atas menunjukan bahwa data berdistribusi secara normal karena titik-titik (Plot) mengikuti garis diagonal.

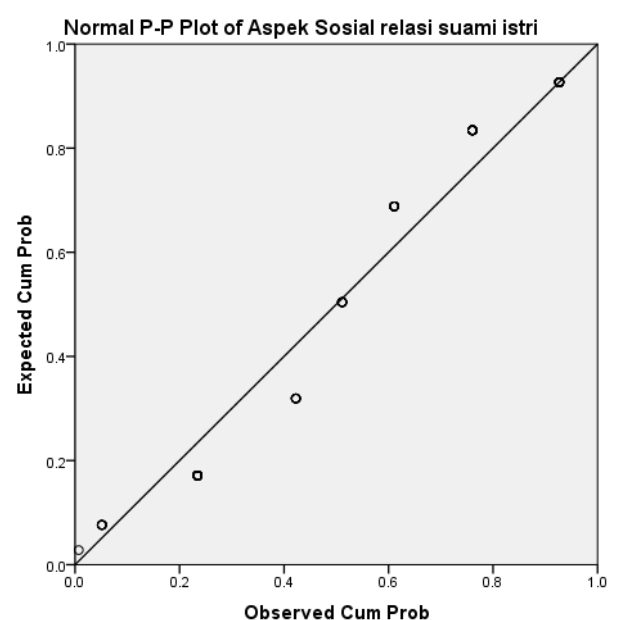

Gambar 2. P-P Plot Aspek Sosial

Indikator 3 - Aspek Moral Relasi Suami-Istri

Dari gambar P-P plot dari indikator 3 aspek moral relasi suami-istri di atas menunjukan bahwa data berdistribusi secara normal karena titik-titik (Plot) mengikuti garis diagonal.

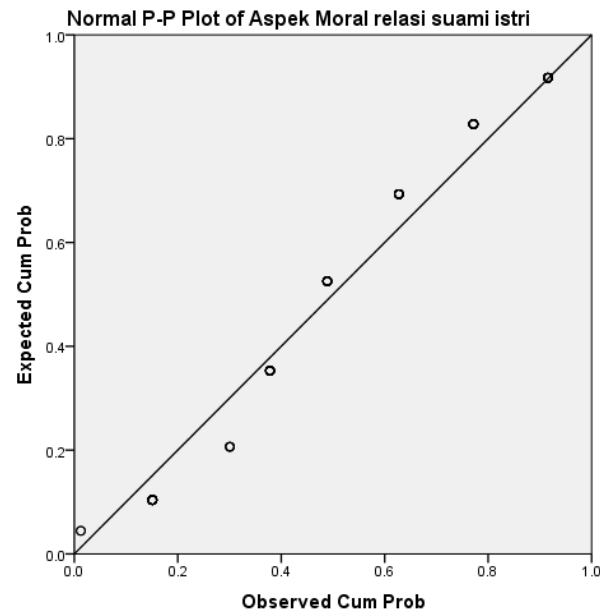

Gambar 3. P-Plot Aspek Moral

\section{Indikator 4 - Aspek Fisik Relasi Suami-Istri}

Dari gambar P-P plot dari indikator 4 aspek fisik relasi suami-istri di atas menunjukan bahwa data berdistribusi secara normal karena titik-titik (Plot) mengikuti garis diagonal. 


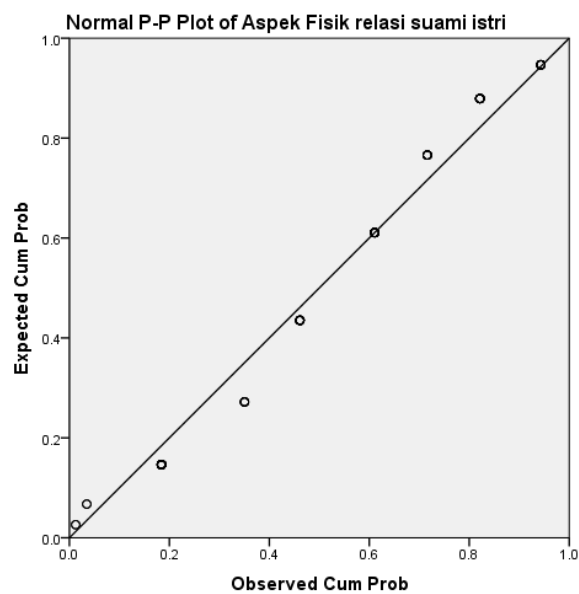

Gambar 4. P-Plot Aspek Fisik

Selanjutnya, uji normalitas terhadap setiap indikator dalam dimensi dua (D2) sebagai berikut:

\begin{tabular}{|c|c|}
\hline \multicolumn{2}{|c|}{ Estimated Distribution Parameters } \\
\hline & Relasi Orang Tua dan Anak \\
\hline Location & 97.2444 \\
\hline Distribution $\overline{\text { Scale }}$ & 7.85874 \\
\hline The cases are unweigh & \\
\hline
\end{tabular}

Tabel 2. Distribusi Parameter D2 - Dimensi Relasi orang Tua-Anak

Uji normalitas setiap indikator D2 Dimensi Relasi orang Tua-Anak sebagai berikut:

Indikator 5 - Aspek Teologis Relasi Orang Tua-Anak

Dari gambar P-P plot dari Indikator 5 Aspek Teologis Relasi Orang Tua dan Anak di atas menunjukan bahwa data berdistribusi secara normal karena titik-titik (Plot) mengikuti garis diagonal.

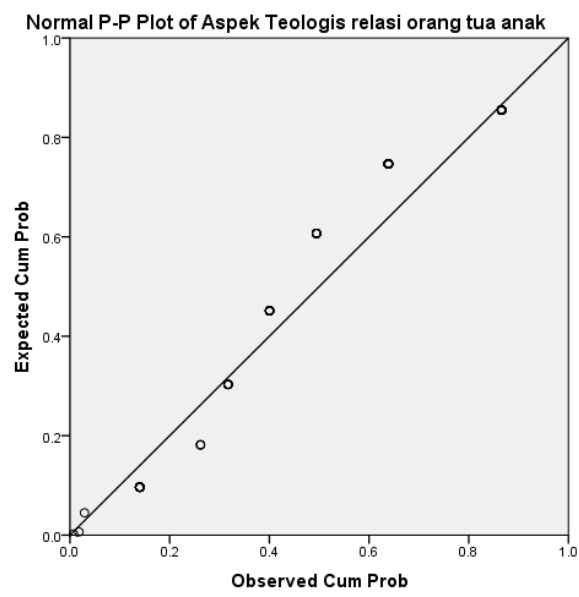

Gambar 5. P-Plot Aspek Teologis
Indikator 6 - Aspek Sosial Relasi Orang Tua-Anak

Dari gambar P-P plot dari Indikator 6 Aspek Sosial Relasi Orang Tua dan Anak diatas menunjukan bahwa data berdistribusi secara normal karena titiktitik (Plot) mengikuti garis diagonal.

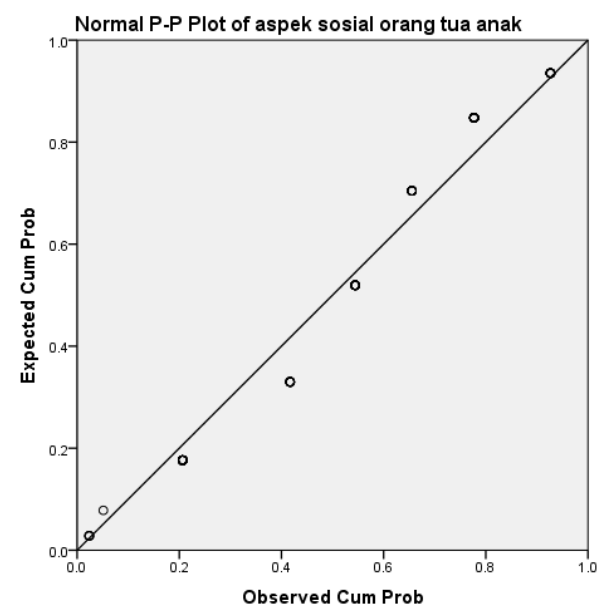

Gambar 6. P-Plot Aspek Sosial

Indikator 7 - Aspek Moral Relasi Orang Tua-Anak

Dari gambar P-P plot dari Indikator 7 aspek moral relasi orang tua dan anak di atas menunjukan bahwa data berdistribusi secara normal karena titiktitik (Plot) mengikuti garis diagonal.

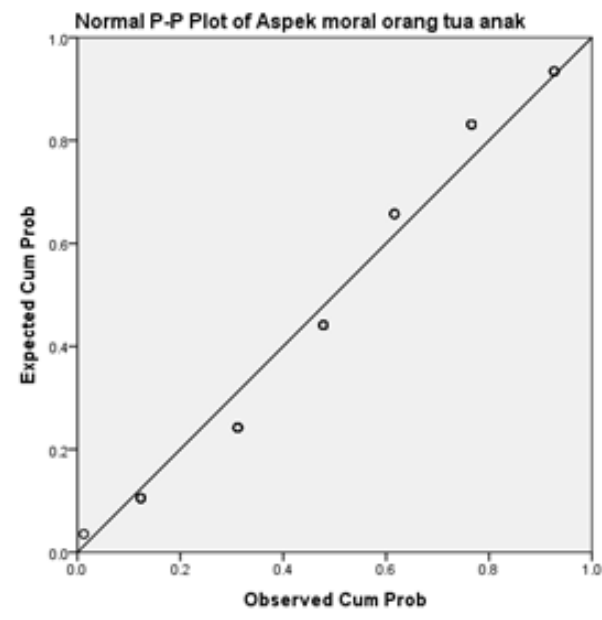

Gambar 7. P-Plot Aspek Moral

Indikator 8 - Aspek Fisik Relasi Orang Tua-Anak

Dari gambar P-P plot dari indikator aspek fisik relasi orang tua dan anak di atas menunjukan bahwa data berdistribusi secara normal karena titiktitik (Plot) mengikuti garis diagonal. 


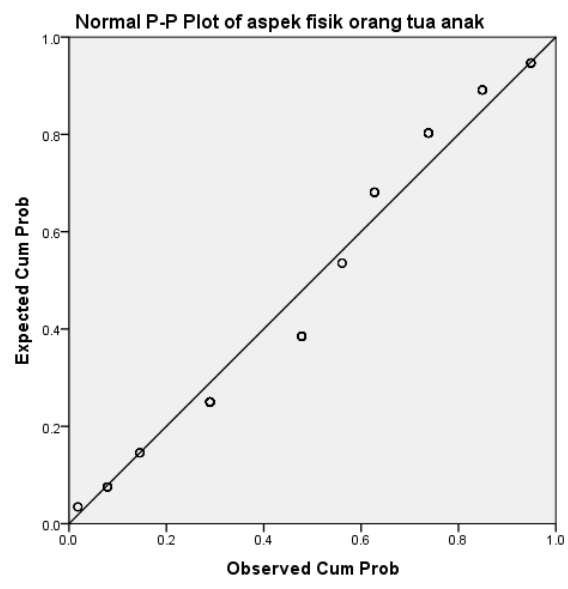

Gambar 8. P-Plot Aspek Fisik

\section{Uji Linearitas}

Uji linieritas dilakukan untuk melihat apakah persamaan regresi $\mathrm{Y}=\mathrm{a}+\mathrm{b} \mathrm{X}_{\mathrm{n}}$ berbentuk persamaan linier atau tidak dengan melihat besarnya koefisien $P$ Value. Dua variabel dikatakan mempunyai hubungan yang linier bila nilai linearity kurang dari 0,05 atau deviation from linearity lebih dari 0,05.

Hasil Uji Linieritas Varibel x ke Y implementasi etika Kristen dalam keluarga berdasarkan Surat Efesus 5:22-6:4 di kalangan Badan Pengurus Jemaat GKII propinsi Jawa Tengah dapat dilihat dalam Tabel 3 di bawah ini:

\begin{tabular}{|c|c|c|c|c|c|c|c|}
\hline & & & $\begin{array}{l}\text { Sum of } \\
\text { Squares }\end{array}$ & $\mathrm{Df}$ & $\begin{array}{c}\text { Mean } \\
\text { Square }\end{array}$ & $\mathrm{F}$ & Sig. \\
\hline \multirow{5}{*}{$\begin{array}{l}\text { Implementasi etika Kristen } \\
\text { dalam keluarga menurut } \\
\text { Efesus 5:22-6:4 di kalangan } \\
\text { Badan Pengurus Jemaat GKII } \\
\text { propinsi Jawa Tengah }\end{array}$} & \multirow{3}{*}{$\begin{array}{l}\text { Between } \\
\text { Groups }\end{array}$} & (Combined) & 17656.256 & 26 & 679.087 & 23.103 & .000 \\
\hline & & Linearity & 16905.184 & 1 & $\begin{array}{r}16905.18 \\
4\end{array}$ & $\begin{array}{r}575.13 \\
0\end{array}$ & .000 \\
\hline & & $\begin{array}{l}\text { Deviation from } \\
\text { Linearity }\end{array}$ & 751.072 & 25 & 30.043 & 1.022 & .455 \\
\hline & \multicolumn{2}{|c|}{ Within Groups } & 1851.800 & 63 & 29.394 & & \\
\hline & \multicolumn{2}{|l|}{ Total } & 19508.056 & 89 & & & \\
\hline
\end{tabular}

Tabel 3. ANOVA Table Linearity

Dari output pengujian linieritas Variabel $\mathrm{X}$ ke $\mathrm{Y}$ di atas, menunjukan nilai signifikansi liniearity adalah 0,000 dan deviation from linierity 0,455 lebih besar dengan 0,05 maka dapat disimpulkan bahwa persamaan refgresi terbukti berbentuk linear.

\section{Uji Homogenitas}

Uji homogenitas dimaksudkan untuk memperlihatkan bahwa dua atau lebih kelompok data sampel berasal dari populasi yang memiliki variansi yang sama. Pada analisis regresi, persyaratan analisis yang dibutuhkan adalah galat regresi untuk setiap pengelompokan berdasarkan variabel terikatnya memiliki variansi yang sama.

Test of Homogeneity of Variances

\begin{tabular}{|c|c|c|c|}
\hline Levene Statistic & df1 & df2 & Sig. \\
\hline 1.199 & 17 & 63 & .291 \\
\hline
\end{tabular}

Tabel 4. Uji Homogenitas D1. Relasi Suami-Istri
Relasi suami-istri dengan implementasi etika Kristen dalam keluarga berdasarkan Surat Efesus 5:22-6:4 di kalangan Badan Pengurus Jemaat GKII Propinsi Jawa Tengah berdasarkan analisa data SPSS 20 untuk uji homogenitas antara variabel $\mathrm{Y}$ dengan dimensi $\left(\mathrm{D}_{1)}\right.$ relasi suami-istri (Tabel 3 di atas) maka karena $p$-value $=0,291>0,05$ maka dapat disimpulkan data diambil dari sampel yang homogen.

Test of Homogeneity of Variances

\begin{tabular}{|l|l|l|l|}
\hline Levene Statistic & df1 & df2 & Sig. \\
\hline 3.458 & 19 & 64 & .078 \\
\hline
\end{tabular}

Tabel 5. Uji Homogenitas D2. Relasi Orang TuaAnak

Relasi orang tua-anak dengan implementasi etika Kristen dalam keluarga berdasarkan Surat Efesus 5:22-6:4 di kalangan Badan Pengurus Jemaat GKII Propinsi Jawa Tengah berdasarkan hasil analisa data SPSS 20 untuk uji homogenitas antara variabel $\mathrm{Y}$ 
dengan dimensi $\mathrm{D}_{2}$ relasi orang tua dan anak (Tabel 3) diketahui karena $p$-value $=0,078>0,05$ maka dapat disimpulkan data diambil dari sampel yang homogen.

\section{Uji Hipotesis}

Hipotesis pertama yaitu: "Tingkat implementasi Etika Kristen dalam keluarga berdasarkan Surat Efesus 5:22-6:4 dalam keluarga BPJ GKII di Propinsi Jawa Tengah" berada dalam kategori
“Tinggi." Untuk menjawab hipotesa pertama, peneliti menerapkan 3 kategori kecenderungan implementasi etika Kristen dalam keluarga berdasarkan Surat Efesus 5:22-6:4 di kalangan Badan Pengurus Jemaat GKII propinsi Jawa Tengah (Variabel Y) yaitu: (a) rendah, (b) sedang dan (c) tinggi. Analisis data dilakukan dengan confidence interval pada taraf signifikansi 5\% dan dihasilkan dalam Tabel 6. Interval di bawah ini sebagai berikut:

\begin{tabular}{|c|c|c|c|c|}
\hline & Statistic & Std. Error \\
\hline \multirow{13}{*}{$\begin{array}{l}\text { Implementasi etika Kristen } \\
\text { dalam keluarga menurut Efesus } \\
\text { 5:22-6:4 di kalangan Badan } \\
\text { Pengurus Jemaat GKII propinsi } \\
\text { Jawa Tengah }\end{array}$} & \multicolumn{2}{|l|}{ Mean } & 198.7222 & 1.56060 \\
\hline & \multirow{2}{*}{$\begin{array}{l}\text { 95\% Confidence } \\
\text { Interval for Mean }\end{array}$} & Lower Bound & 195.6213 & \\
\hline & & Upper Bound & 200.8231 & \\
\hline & \multicolumn{2}{|l|}{$5 \%$ Trimmed Mean } & 198.9568 & \\
\hline & \multicolumn{2}{|l|}{ Median } & 199.0000 & \\
\hline & \multicolumn{2}{|l|}{ Variance } & 219.192 & \\
\hline & \multicolumn{2}{|l|}{ Std. Deviation } & 14.80512 & \\
\hline & \multicolumn{2}{|l|}{ Minimum } & 157.00 & \\
\hline & \multicolumn{2}{|l|}{ Maximum } & 225.00 & \\
\hline & \multicolumn{2}{|l|}{ Range } & 68.00 & \\
\hline & \multicolumn{2}{|l|}{ Interquartile Range } & 24.75 & \\
\hline & \multicolumn{2}{|l|}{ Skewness } & -.196 & .254 \\
\hline & \multicolumn{2}{|l|}{ Kurtosis } & -.346 & .503 \\
\hline
\end{tabular}

Tabel 6. Hasil Uji Hipotesis 1

Dari hasil pembagian nilai range dibuatlah tabel interval berikut:

\begin{tabular}{|c|c|c|}
\hline Interval & Kategori & $\begin{array}{c}\text { Nilai lower dan Upper } \\
\text { Bound variabel Y }\end{array}$ \\
\hline $156-178$ & Rendah & \\
\hline $179-201$ & Sedang & $\begin{array}{c}\mathbf{1 9 5 . 6 2 1 3}-\mathbf{2 0 0 . 8 2 3 1} \\
\text { (Sedang ) }\end{array}$ \\
\hline $202-224$ & Tinggi & \\
\hline
\end{tabular}

Tabel 7. Tabel Interval

Pengujian hipotesis pertama menunjukkan bahwa tingkat implementasi etika Kristen dalam keluarga Badan Pengurus Jemaat GKII Propinsi Jawa Tengah (Y) berada pada kategori "sedang" dan bukan "tinggi". Dengan demikian hipotesis pertama dinyatakan ditolak.

Kedua, hasil uji hipotesis membuktikan bahwa "aspek fisik" dalam relasi suami-istri lebih dominan menentukan implementasi etika Kristen dalam keluarga BPJ GKII Jawa Tengah berdasarkan Surat
Efesus 5:22-6:4. Uji hipotesis terhadap signifikansi regresi setiap indikator yang dominan mempengaruhi implementasi etika Kristen sebagai berikut:

Model Summary

\begin{tabular}{|c|c|c|c|c|}
\hline Model & R & R Square & $\begin{array}{c}\text { Adjusted R } \\
\text { Square }\end{array}$ & $\begin{array}{c}\text { Std. Error of } \\
\text { the Estimate }\end{array}$ \\
\hline 1 & $.808^{\mathrm{a}}$ & .652 & .648 & 8.78181 \\
\hline
\end{tabular}

a. Predictors: (Constant), Aspek Teologis relasi suami istri

Tabel 8. Persentase Signifikansi Regresi Aspek Teologis Relasi Suami-Istri

Koefisien korelasi (R) aspek teologis relasi suami-istri sebesar 0.808 dan koefisien determinasi sebesar 0,652 memberikan kontribusi terhadap implementasi etika Kristen dalam keluarga Badan Pengurus Jemaat GKII Propinsi Jawa Tengah (Variabel Y) sebesar $65,2 \%$. 


\begin{tabular}{|c|c|c|c|c|}
\hline \multicolumn{5}{|c|}{ Model Summary } \\
\hline$\overline{\mathrm{Mod}}$ & $\mathrm{R}$ & R Square & $\begin{array}{c}\text { Adjusted R } \\
\text { Square }\end{array}$ & $\begin{array}{l}\text { Std. Error of } \\
\text { the Estimate }\end{array}$ \\
\hline 1 & $.775^{\mathrm{a}}$ & .601 & .596 & 9.41003 \\
\hline
\end{tabular}

a. Predictors: (Constant), Aspek Sosial relasi suami istri

Tabel 9. Persentase Signifikansi Regresi

Aspek Sosial Relasi Suami-Istri

Koefisien korelasi (R) Aspek Sosial Relasi Suami-Istri sebesar 0,775 dan koefisien determinasi sebesar 0,601 memberikan kontribusi terhadap Variabel Y sebesar 60,1\%.

\section{Model Summary}

\begin{tabular}{|c|c|c|c|c|}
\hline Model & R & R Square & $\begin{array}{c}\text { Adjusted R } \\
\text { Square }\end{array}$ & $\begin{array}{c}\text { Std. Error of } \\
\text { the Estimate }\end{array}$ \\
\hline 1 & $.764^{\mathrm{a}}$ & .584 & .579 & 9.60716 \\
\hline
\end{tabular}

a. Predictors: (Constant), Aspek Moral relasi suami istri

Tabel 10. Persentase Signifikansi Regresi

Aspek Moral Relasi Suami-Istri

Koefisien korelasi (R) Aspek Moral Relasi Suami-Istri sebesar 0,764 dan koefisien determinasi sebesar 0,584 memberikan kontribusi terhadap Variabel Y sebesar 58,4\%.

\section{Model Summary}

\begin{tabular}{|c|c|c|c|c|}
\hline Model & R & R Square & $\begin{array}{c}\text { Adjusted R } \\
\text { Square }\end{array}$ & $\begin{array}{c}\text { Std. Error of } \\
\text { the Estimate }\end{array}$ \\
\hline 1 & $.881^{\mathrm{a}}$ & .777 & .774 & 7.03239 \\
\hline
\end{tabular}

a. Predictors: (Constant), Aspek Fisik relasi suami istri

Tabel 11. Persentase Signifikansi Regresi Aspek Fisik Relasi Suami-Istri

Koefisien korelasi (R) aspek fisik relasi suami-istri sebesar 0,881 dan koefisien determinasi sebesar 0,777 memberikan kontribusi terhadap Variabel Y sebesar 77,7 \%.

\section{Model Summary}

\begin{tabular}{|c|c|c|c|c|}
\hline Model & R & R Square & $\begin{array}{c}\text { Adjusted R } \\
\text { Square }\end{array}$ & $\begin{array}{c}\text { Std. Error of } \\
\text { the Estimate }\end{array}$ \\
\hline 1 & $.822^{\mathrm{a}}$ & .676 & .673 & 8.47239 \\
\hline
\end{tabular}

a. Predictors: (Constant), aspek teologis relasi orang tua dan anak

Tabel 12. Persentase Signifikansi Regresi Aspek Teologis Relasi Orang Tua-Anak

Koefisien korelasi (R) aspek teologis relasi orang tua-anak sebesar 0,822 dan koefisien determinasi sebesar 0,676 memberikan kontribusi terhadap Variabel Y sebesar 67,6\%.

Model Summary

\begin{tabular}{|c|c|c|c|c|}
\hline Model & $\mathrm{R}$ & R Square & $\begin{array}{c}\text { Adjusted R } \\
\text { Square }\end{array}$ & $\begin{array}{c}\text { Std. Error of } \\
\text { the Estimate }\end{array}$ \\
\hline 1 & $.821^{\mathrm{a}}$ & .674 & .670 & 8.50432 \\
\hline
\end{tabular}

a. Predictors: (Constant), Aspek Sosial relasi orang tua dan anak

Tabel 13. Persentase Signifikansi Regresi Aspek Sosial Relasi Orang Tua-Anak

Koefisien korelasi (R) aspek sosial relasi orang tua-anak sebesar 0,821 dan koefisien determinasi sebesar 0,674 memberikan kontribusi terhadap Variabel Y sebesar 67,4\%.

Model Summary

\begin{tabular}{|l|c|r|r|r|}
\hline Model & R & \multicolumn{1}{c|}{$\begin{array}{c}\text { R } \\
\text { Square }\end{array}$} & $\begin{array}{r}\text { Adjusted } \\
\text { R Square }\end{array}$ & $\begin{array}{r}\text { Std. Error of } \\
\text { the Estimate }\end{array}$ \\
\hline 1 & $.809^{\mathrm{a}}$ & .655 & .651 & 8.75062 \\
\hline
\end{tabular}

a. Predictors: (Constant), Aspek Moral relasi orang tua dan anak

Tabel 14. Persentase Signifikansi Regresi Aspek Moral Relasi Orang Tua-Anak

Koefisien korelasi (R) aspek moral relasi orang tua-anak sebesar 0,809 dan koefisien determinasi sebesar 0,655 memberikan kontribusi terhadap Variabel Y sebesar 65,5\%.

Model Summary

\begin{tabular}{|l|c|r|r|r|}
\hline $\begin{array}{l}\text { Mode } \\
1\end{array}$ & $\mathrm{R}$ & $\begin{array}{c}\mathrm{R} \\
\text { Square }\end{array}$ & $\begin{array}{c}\text { Adjusted R } \\
\text { Square }\end{array}$ & $\begin{array}{r}\text { Std. Error of } \\
\text { the Estimate }\end{array}$ \\
\hline 1 & $.782^{\mathrm{a}}$ & .611 & .607 & 9.28583 \\
\hline
\end{tabular}

a. Predictors: (Constant), Aspek fisik relasi orang tua dan anak

Tabel 14. Persentase Signifikansi Regresi Aspek Fisik Relasi Orang Tua-Anak 
Koefisien korelasi (R) aspek fisik relasi orang tua-anak sebesar 0,782 dan koefisien determinasi sebesar 0,611 memberikan kontribusi terhadap Variabel Y sebesar 61,1\%.
Hasil uji hipotesis dapat dilihat dalam rekapitulasi hasil perhitungan kontribusi setiap indikator Exogenous Varible $(X)$ terhadap Endogenous Varible $(Y)$ dalam Tabel 4 berikut:

\begin{tabular}{|l|l|c|c|c|}
\hline No & Indikator & r & r square & Kontribusi(\%) \\
\hline 1 & Aspek Teologis relasi suami istri & 0,808 & 0,652 & 65,2 \\
\hline 2 & Aspek Sosial relasi suami istri & 0,775 & 0,601 & 60,1 \\
\hline 3 & Aspek Moral relasi suami istri & 0,764 & 0,584 & 58,4 \\
\hline 4 & Aspek Fisik relasi suami istri & 0,881 & 0,777 & 77,7 \\
\hline 5 & Aspek Teologis relasi orang tua dan anak & 0,822 & 0,676 & 67,6 \\
\hline 6 & Aspek Sosial relasi orang tua dan anak & 0,821 & 0,674 & 67,4 \\
\hline 7 & Aspek Moral relasi orang tua dan anak & 0,809 & 0,655 & 65,5 \\
\hline 8 & Aspekfisik relasi orang tua dan anak & 0,782 & 0,611 & 61,1 \\
\hline
\end{tabular}

Tabel 15. Rekapitulasi Hasil Uji Signifikansi Regresi Tiap Indikator

Tabel di atas menunjukkan persentase rekapitulasi hasil uji signifikansi regresi variable $\mathrm{X}$ terhadap Y di mana indikator Aspek Fisik Relasi SuamiIstri $\left(I_{4}\right)$ ternyata yang paling dominan membentuk Implementasi etika Kristen dalam keluarga BPJ GKII Propinsi Jawa Tengah yaitu sebesar 77,7\%. Dengan demikian hipotesis kedua yang menduga indikator Aspek Teologis Relasi Suami-Istri lebih dominan ditolak.

\section{PEMBAHASAN}

Pertama, hipotesis pertama ditolak, karena hasil penelitian menunjukkan bahwa implementasi etika Kristen dalam keluagra BPJ GKII Propinsi Jawa Tengah berada dalam kategori "sedang" dan bukan "tinggi". Meskipun dalam wawancara dengan para ketua BPJ dari beberapa gereja lokal GKII di Jawa Tengah terindikasi bahwa penerapan etika Kristen dalam keluarga anggota BPJ sudah tinggi (Lukas, Sugiyanto, Susanto, 2020). Namun, hasilnya berbeda. Jika dicermati dari isi wawancara di atas, maka hal ini disebabkan bahwa para Gembala Sidang memakai indikator yang kurang tepat dalam mengukur tingkat penerapan etika Kristen dalam keluarga anggota BPJ-nya. Misalnya, kesetiaan keluarga setiap anggota BPJ menghadiri Ibadah Minggu, keaktifan anggota BPJ mengikuti kegiatan gereja bersama seluruh anggota keluar- ganya dan keterlibatan anggota keluarga BPJ dalam tugas pelayanan di gereja. Semua hal tersebut belum dapat mengindikasikan bahwa tingkat implementasi etika Kristen dalam sebuah keluarga itu sudah tinggi. Pemakaian indikator yang kurang tepat di atas memberikan petunjuk bahwa para pemimpin gereja cenderung mempraktikkan pragmatisme yang lebih mengedepankan aspek pemasaran dan organisasi yang tanpa disadari telah menggeser realitas teologi gereja sebagai Tubuh Kristus (Webber, 1999, p. 75). Semestinya, para Gembala Sidang memakai indikator yang dimaksud dalam Surat Efesus 5:22-6:4, sebagai bagian dari misi gereja sebagai tubuh Kristus. Selanjutnya, riset Hastuti menemukan bahwa pendidikan agama Kristen semestinya mulai dibangun dari keluarga, lalu bersinergi dengan gereja dan sekolah (Hastuti, 2013, p. 48). Lemahnya sinergitas ketiga lembaga tersebut mengakibatkan implementasi etika Kristen dalam keluarga kurang berpotensi mencapai kategori tinggi. Sebagai simpulan, penekanan penggembalaan pragmatis yang lebih berorientasi kepada pemasaran organisasi gereja dan lemahnya sinergi antara gereja, keluarga dan sekolah menghambat optimalisasi implementasi etika Kristen dalam keluarga, khususnya keluarga BPJ GKII Propinsi Jawa Tengah.

Hipotesis Kedua, menunjukkan sumbangsih Aspek Fisik Relasi Suami-Istri yang paling dominan 
menentukan implementasi etika Kristen dalam keluarga BPJ GKII propinsi Jawa Tengah, disbandingkan dengan aspek lainnya (Hal ini terjadi besar kemungkinan dipengaruhi pandemi Covid-19 yang membawa dampak buruk bagi kehidupan ekonomi para anggota BPJ tersebut di atas (mengingat pengambilan data pada awal Januari-Mei 2020). Dalam masa pandemi ini, fokus kehidupan para anggota BPJ lebih mengutamakan pemenuhan kebutuhan dan kesehatan fisik guna mengantisipasi dampak negatif penyebaran Covid-19 terhadap kelangsungan hidup keluarganya.

Hal ini didukung oleh survei nasional dari Bilangan Research Center (BRC) yang menemukan faktor-faktor penyebab utama pertumbuhan jemaat, yang tertinggi ialah faktor "perpindahan umat dari gereja lain" sebesar $45,7 \%$ dan kedua adalah faktor biologis atau pertumbuhan biologis sebesar $23,8 \%$, dalam arti bahwa ada semakin banyak anak-anak yang lahir dari pasangan suami-istri Kristen mengikuti orang tuanya ke gereja (Irawan \& Budijanto, 2020, p. 22-23). Temuan BRC tersebut menjelaskan bahwa implementasi aspek teologis dan aspek fisik dalam sebuah keluarga terkait erat satu sama lain dan sangat mempengaruhi pertumbuhan gereja. Maksudnya, sebuah keluarga Kristen yang berhasil membimbing anak-anaknya untuk mengikuti orang tuanya pergi ke gereja, maka hal inilah yang menyebabkan terjadinya pembangunan tubuh Kristus yang berdampak kepada pertumbuhan gereja. Temuan BRC tersebut sudah ditemukan terlebih dahulu melalui riset yang dilakukan Kraweic terhadap kehidupan keluarga dalam gereja mula-mula (Early Christianity) yang membuktikan bahwa aspek teologis/spiritual dan aspek fisik tidak bertentangan melainkan dapat dilink untuk mencapai keselamatan yang seutuhnya (Kraweic, 2003, p. 283). Faktor ini yang secara otomatis mendorong terjadinya pertumbuhan gereja. Hal ini pula yang dimaksudkan oleh Paulus dalam Surat Efesus 6:22-6:4, di mana keluarga Kristen yang mengimplementasikan firman Allah dengan setia, maka akan menghasilkan pembangunan tubuh Kristus yang berdampak kepada pertumbuhan gereja yang sehat dan signifikan. Dengan demikian pengertian ke- luarga manusia dalam konteks ini merupakan jemaat mini (Budiyana, 2018, p. 141). Sebagai simpulan dalam uji hipotesis kedua ini ialah bahwa gereja selama ini lebih sering memperhatikan aspek rohani, sementara aspek fisik sering terabaikan. Untuk itu, cara pandang gereja terhadap kedua aspek ini perlu diperbaiki yaitu dengan cara memberi perhatian atau penghargaan yang proporsional terhadap kedua aspek tersebut, karena keduanya saling terkait erat (link) satu sama lain sebagai katalisator utama yang mempengaruhi implementasi etika Kristen dalam keluarga. Dengan demikian, aspek fisik dan teologis memainkan peranan utama implementasi etika dalam keluarga yang mendorong pembangunan tubuh Kristus dan pertumbuhan gereja yang sehat.

\section{KESIMPULAN}

Tingkat implementasikan etika Kristen dalam keluarga berdasarkan Surat Efesus 5:22-6:4di kalangan BPJ GKII di Propinsi Jawa Tengah masih berada dalam kategori "Sedang". Oleh karena itu implementasikan etika Kristen dalam keluarga BPJ GKII di Propinsi Jawa Tengah perlu ditingkatkan dengan cara memberikan perhatian khusus kepada setiap aspek yang ada dalam relasi suami-istri dan orang tua-anak, yaitu dengan melakukan kegiatan atau program yang tepat guna untuk setiap aspek tersebut, tentunya melibatkan Badan Pengurus Daerah GKII Propinsi Jawa Tengah masing-masing.

Perhatian kepada aspek fisik dalam dimensi relasi suami-istri yang merupakan indikator yang paling dominan menentukan implementasi etika Kristen dalam keluarga BPJ GKII Propinsi Jawa Tengah, dapat dilakukan dengan strategi memberikan bantuan khusus (reinforcement) dimana pasangan suami-istri BPJ GKII di Jawa Tengah diberi dukungan finansial, terutama mengantisipasi dampak pandemi Covid-19 dengan cara melakukan seminar tentang Entrepreneurship (Kewirausahaan), Bisnis Online, informasi tentang usaha ekonomi kreatif dan lain-lain.

Selain itu, untuk aspek teologis, perhatian bisa diberikan dalam bentuk mengadakan Persekutuan Pasutri (Pasangan Suami-istri) di setiap gereja 
lokal masing-masing, hal ini mengingat banyak gereja lokal dalam denominasi GKII di Jawa Tengah yang lebih mengutamakan Persekutuan Kaum Wanita (Perkawan) dan Persekutuan Kaum Pria (Perkaria).

Kemudian, perhatian dalam aspek sosial bisa dilakukan dengan menyelenggarakan kegiatan retreat keluarga untuk menyediakan waktu keluarga (family time) yang lebih leluasa kepada para anggota keluarga. Termasuk kegiatan Weekend ALMA yang

\section{DAFTAR RUJUKAN}

Antone, H. S. (2010). Pendidikan Kristiani Kontekstual. Jakarta: BPK Gunung Mulia.

Arikunto, S. (2008). Metodologi Penelitian. Yogyakarta: Bina Aksara.

Banks, Stevens, R., R. Paul. (2012). The Complete Book of Everyday Christianity A-E. Bandung: Kalam Hidup.

Barclay, W. (2003). Pemahaman Alkitab Setiap Hari:

Surat-Surat Galatia \& Efesus. Jakarta: BPK Gunung Mulia.

Beeke, J. R. (2019). Keindahan \& Kemuliaan Mempelai Wanita Kristus. Surabaya: Penerbit Momentum.

Bertens, K. (1994). Etika. Jakarta: PT. Gramedia Pustaka Utama.

Biyanto, A., \& Limengka, A. (2019). Apa Yang Kau Bawa Pulang? (2nd ed.). Surabaya: Penerbit Momentum.

Budiyana, H. (2018). Perspektif Alkitab Terhadap Keluarga Kristen. Regula Fidei: Jurnal Pendidikan Agama Kristen, 3.

Calvin, J. (2015). John Calvin dan Perdagangan. Surabaya: Penerbit Momentum.

Christenson, L. (n.d.). Keluarga Kristen. Semarang: Yayasan Persekutuan Betania.

Coles, R. (2000). Menumbukan Kecerdasan Moral Pada Anak. Jakarta: PT. Gramedia Pustaka Utama.

Darmaputera, E. (2009). Etika Sederhana untuk Semua: Perkenalan Pertama (13th ed.). Jakarta: BPK Gunung Mulia. khusus diselenggarakan bagi Pasutri, sehingga memiliki durasi Quality Time yang lebih banyak. Selanjutnya, perhatian untuk aspek moral dapat dilakukan dengan melakukan konseling keluarga yang dilakukan oleh gembala sidang atau Tim pastoral maupun konselor yang ditunjuk secara khusus. Demikian pula kegiatan-kegiatan penyegaran iman dan sejenisnya seperti Camp Pria Sejati dan Wanita Bijak yang dikoordinir oleh Badan Pengurus Daerah masing-masing.

Daud, D. (2020). Social Distancing dan Budaya Kita. In Pandemik COVID-19: Persoalan dan Refleksi di Indonesia. Surabaya: Yayasan Kita Menulis.

Debora, Han, K., Chandra. (2020). Pentingnya Peranan Guru Kristen Dalam Membentuk Karakter Siswa Dalam Pendidikan Kristen: Sebuah Kajian Etika Kristen. Diligentia: Journal of Theology and Christian Education, 2, 1-14.

Dewi, P. M. (2012). Partisipasi Tenaga Kerja Perempuan dalam Meningkatkan Pendapatan Keluarga. Jurnal Ekonomi Kuantitatif Terapan, 5, 119-124.

Drescher, J. M. (2009). Tujuh Kebutuhan Anak (4th ed.). Jakarta: BPK Gunung Mulia.

Groome, T. H. (2011). Pendidikan Agama Kristen, (3rd ed.). Jakarta: BPK Gunung Mulia.

Hadinoto, N. K. A. (2012). Dialog dan Edukasi (12th ed.). Jakarta: BPK Gunung Mulia.

Hastuti, R. (2013). Pendidikan Agma Kristen Dalam Keluarga Sebagai Pusat Bermisi. Jurnal Antusias, 2, 48-59.

Hutahaean, T. (2019). Keluarga Yang Berbuah Bagi Kristus Di Tengah Tantangan Zaman Pascamilenial. Surabaya: Penerbit Momentum.

Irawan, H., \& Budijanto, B. (2020). Kunci Pertumbuhan Gereja di Indonesia. Jakarta: Yayasan Bilangan Research Center.

Kaddi, S. M., Lestari, P., \& Adrian, D. (2020). Komunikasi Keluarga Dalam Pencegahan 
Coronavirus Disease 2019. Jurnal Ilmu Komunikasi, 18, 63-74.

Kraft, C. H. (1996). Anthropology for Christian Witness. New York: Orbis Books.

Longkutoy, Sinolungan, Opod, N., Jehosua, Henry. (2015). Hubungan Pola Asuh Orang Tua Dengan Kepercayaan Diri Siswa SMP Kristen Ranotongkor Kabupaten Minahasa. Jurnal e-Biomedik, 1(1), 93-99.

Lukas, J. (2020). Penerapan Etika Kristen Dalam Keluarga.

Mansyur, Abd. R. (2020). Dampak COVID-19 Terhadap Dinamika Pembelajaran Di Indonesia. Education and Learning Journal, 1, 113-123.

McDonald, M. (1999). The Ephesian Church. Singapore: Far Eastern Bible College Press.

Meade, S. (2019). Beri Mereka Kebenaran: Mengajarkan Kebenaran Kekal Kepada Anak-Anak. Surabaya: Penerbit Momentum.

Melgosa, Borges, J. M. (2017). Kekuatan Harapan. Bandung: Indonesia Publishing House.

Morley, P. (2009). 12 Kebiasaan Agar Tumbuh Dalam Kristus. Malang: Penerbit Gandum Mas.

Ngir, D. W. (2014). 10 Kebutuhan Utama Dalam Pernikahan. Bandung: Kalam Hidup.

Nugraheni S., W. (2012). Peran dan Potensi Wanita Dalam Pemenuhan Kebutuhan Ekonomi Keluarga Nelayan. Journal of Educational Social Studies, 1, 104-111.

Nuhamara, D. (2018). Pengutamaan Dimensi Karakter Dalam Pendidikan Agama Kristen. Jurnal Jaffray, 16, 93-115.

Osborne, C. G. (1992). Seni Memahami Pasangan Anda, (2nd ed.). Jakarta: BPK Gunung Mulia.

Otis, D. S. (2003). Membina Anak Bermoral. Bandung: Kalam Hidup.

Pardede, J. (2019). Pacaran, Pernikahan dan Keluarga. Surabaya: Penerbit Momentum.
Parrott III, Parrott, L., Leslie. (1999). Seputar Problema Suami-Istri. Jakarta: Pustaka Delapratasa.

Pratama, H. C. (2012). Cyber Smart Parenting. Bandung: PT. Visi Anugerah Indonesia.

Rochaida, E. (2016). Dampak Pertumbuhan Penduduk Terhadap Ekonomi dan Keluarga Sejahtera di Provinsi Kalimantan Timur. Jurnal Forum Ekonomi, 18, 14-24.

Salaa, J. (2015). Peran Ganda Ibu Rumah Tangga Dalam Meningkatkan Ekonomi Keluarga di Desa Tarohan Kecamatan Beo Kabupaten Kepulauan Talaud. Jurnal Holistik, VIII, 116.

Scheunemann, S. (1988). Romantika Kehidupan Suami-Istri (2nd ed.). Batu, Malang: YPII \& Gandum Mas.

Sproul, R. C. (2005). Etika dan Sikap Orang Kristen (3rd ed.). Malang: Gandum Mas.

Sugiyanto. (2020). Penerapan Etika Kristen Dalam Keluarga.

Susanto. (2020). Penerapan Etika kristen Dalam Keluarga.

Sutanto, H. (2011). Perjanjian Baru Interlinear dan Konkordansi. Jakarta: Lembaga Alkitab Indoensia.

Tafonao, T. (2018). Peran Pendidikan Agama Kristen Dalam Keluarga Terhadap perilaku Anak. Edudikara: Jurnal Pendidikan Dan Pembelajaran, 3, 121-133.

Thomas, M. W. I. (2000). Hidup Yesus Dalam Hidupku (5th ed.). Bandung: Kalam Hidup.

Tong, S. (2019). Orang Kristen dan Harta. Surabaya: Penerbit Momentum.

Verkuyl, J. (1985). Etika kristen. Jakarta: BPK Gunung Mulia.

Webber, R. E. (1999). Ancient-Future Faith: Rethingking Evangelism for a Postmodern World. Baker books.

Wiersbe, W. W. (1983). Kaya di Dalam Kristus. Bandung: Kalam Hidup. 